\title{
Takotsubo syndrome - adding pieces to a complex puzzle
}

\author{
Athanassios Manginas ${ }^{1 * \dagger}$ (D), Angelos G. Rigopoulos ${ }^{2 \dagger}$, Boris Bigalke ${ }^{3}$, Stefanos Sakellaropoulos ${ }^{2}$, Muhammad Ali $^{4}$, \\ Sophie Mavrogeni ${ }^{5}$ and Michel Noutsias ${ }^{2}$
}

\begin{abstract}
Takotsubo syndrome, a form of acutely decompensated heart failure, has drawn interest because of its intriguing pathophysiology and therapeutic dilemmas. In their recent work in BMC Cardiovascular Disorders, AbanadorKamper et al. describe the therapy management in these patients and add valuable information on cardiovascular magnetic resonance imaging evolution.
\end{abstract}

Keywords: Cardiac magnetic resonance imaging, Clinical presentation, Heart failure, Takotsubo syndrome, Treatment

\section{Letter to the Editor:}

We read with great interest the publication by AbanadorKamper et al. [1], in which the investigators report on the clinical outcome and the medical therapy used in every day practice. In this investigation on 72 patients with Takotsubo syndrome (TTS), the medical treatment followed the recommendations for acute coronary syndrome and acute decompensated heart failure (ADHF). The reported inhospital complications rate was $5.6 \%$, and the 2-year major adverse cardiac events (MACE) was 12\%. In-hospital mortality was only $1 \%$, and the mortality at 2 and 3 years were 5 and $8 \%$, respectively. The authors attribute this favorable outcome, at least partly, to a more intense use of medications right with the onset of the TTS. It should be noted though that, in the present small and retrospective study, long term double and single antiplatelet therapy yielded comparable MACE rates of 6 and 4\%, respectively. In contrast, in the much larger International Takotsubo Syndrome Registry of 1750 patients, in-hospital complications were observed in $21.8 \%$ of patients, while the rate of major adverse cardiac and cardiovascular events during the first 30 days after admission was $7.1 \%$, with a mortality of $5.9 \%$. During follow-up, mortality was $5.6 \%$ per patient-year [2]. TTS was previously believed to have a relatively benign

\footnotetext{
* Correspondence: nassoseft@yahoo.com

${ }^{\dagger}$ Equal contributors

${ }^{1}$ Interventional Cardiology and Cardiology Department, Mediterraneo

Hospital, Ilias Street 8-12, GR-16675 Glyfada, Greece

Full list of author information is available at the end of the article
}

prognosis, however, is now regarded as a form of acute, reversible, heart failure syndrome with potentially serious clinical complications. A recent Position Statement from the ESC Heart Failure Association aids in clinical decisionmaking and describes the unmet needs for evidence-based therapeutic strategies [3]. Useful data on prescription trends provided by the present study is for example the wide use of long-term antiplatelet treatment for a syndrome more closely resembling ADHF.

The authors should also be congratulated for providing cardiovascular magnetic resonance imaging (CMR) in the acute phase ( 2 days) and at follow-up (2.3 months) in all TTS patients. CMR is an excellent diagnostic modality and, if available, may help in the differential diagnosis between previous myocardial scar and TTS (LGE present or absent respectively) and between acute myocarditis and TTS. In addition, it is more accurate in the detection of apical thrombus, and for the diagnosis of right ventricular involvement. It is regarded complimentary to echocardiogram for documentation of myocardial recovery.

Although first reported in 1990, TTS offers many areas for future investigation, already touched upon by clinicians and scientists. How can the different anatomical variants of TTS be explained [4]? Is the brain (hypothalamic-pituitaryadrenal)-heart interaction predisposing patients to TTS [5]? What is the significance of blood hyperviscocity [6], autonomic imbalance [7] or endothelial dysfunction [8] and could they become therapeutic targets? Besides conservative medical therapy, could psychological or 
behavioral counseling prevent TTS or its recurrences? Finally, are there any longterm consequences and/or risk from recurrences?

Future randomized studies, ideally through national or international TTS collaborations, will certainly advance the field in this fascinating syndrome.

\section{Abbreviations}

ADHF: Acute decompensated heart failure; CMR: Cardiac magnetic resonance; LGE: Late gadolinium enhancement; MACE: Major adverse cardiac events; TTS: Takotsubo syndrome

\section{Acknowledgements}

Not applicable

\section{Funding}

Not applicable

\section{Availability of data and materials}

Not applicable

\section{Authors' contributions}

AM and MN wrote the manuscript, and AM, AGR, BB, SS, MA, SM and MN were involved in critically reviewing the manuscript and made appropriate corrections. All authors approved the final manuscript.

\section{Ethics approval and consent to participate}

Not applicable.

\section{Consent for publication}

Not applicable.

\section{Competing interests}

AM has participated in advisory boards from Astra-Zeneca, Bayer, ELPEN, Actelion, MSD and Novartis. MN has received grants by the Deutsche Forschungsgemeinschaft (DFG) through the Sonderforschungsbereich Transregio 19 "Inflammatory Cardiomyopathy" (SFB TR19) (TP B2), and by the University Hospital Giessen and Marburg Foundation Grant "T cell functionality" (UKGM 10/2009). MN has been consultant to the IKDT (Institute for Cardiac Diagnosis and Therapy GmbH, Berlin) 06/2004-06/2008, and has received honoraria for presentations and/or participated in advisory boards from AstraZeneca, Bayer, Fresenius, Miltenyi Biotech, Novartis, Pfizer and Zoll. $M N$ and $A G R$ are members of the Editorial Board of Cardiovascular Disorders. The remaining authors, i.e. BB, SS, MA and SM declare that they have no conflict of interest.

\section{Publisher's Note}

Springer Nature remains neutral with regard to jurisdictional claims in published maps and institutional affiliations.

\section{Author details}

${ }^{1}$ Interventional Cardiology and Cardiology Department, Mediterraneo Hospital, Ilias Street 8-12, GR-16675 Glyfada, Greece. ${ }^{2}$ Department of Interna Medicine III, Division of Cardiology, Angiology and Intensive Medical Care, University Hospital Halle, Martin-Luther-University Halle, Ernst-Grube-Straße 40, 06120 Halle (Saale), Germany. ${ }^{3}$ Department of Cardiology, Charité Universitätsmedizin Berlin, Campus Benjamin Franklin (CBF), Berlin, Germany. ${ }^{4}$ Department of Cardiology, Asklepios Harzklinik Goslar, Goslar, Germany. ${ }^{5}$ Department of Cardiology, Onassis Cardiac Syrgery Center, Leoforou Andrea Sygrou 356, Kallithea, 17674 Athens, Greece.

Received: 7 September 2017 Accepted: 10 December 2017

Published online: 20 December 2017

\section{References}

1. Abanador-Kamper N, Kamper L, Wolfertz J, Pomjanski W, Wolelf-Putz A, Seyfarth M. Evaluation of therapy management and outcome in Takotsubo syndrome. BMC CVD. 2017;17(1):225.
2. Templin C, Ghadri JR, Diekmann J, et al. Clinical features and outcomes of Takotsubo (Stress) cardiomyopathy. N Engl J Med. 2015;373:929-38.

3. Lyon AR, Bossone E, Schneider B, et al. Current state of knowledge on Takotsubo syndrome: a position statement from the task force on Takotsubo syndrome of the heart failure Association of the European Society of cardiology. Eur J of Heart Failure. 2016;18:8-27.

4. Redfors B, Shao Y, Ali A, Omerovic E. Are the different patterns of stressinduced (Takotsubo) cardiomyopathy explained by regional mechanical overload and demand:supply mismatch in selected ventricular regions? Med Hypotheses. 2013;81:954-60.

5. Wittstein IS, Thiemann DR, Lima JAC, Baughman KL, et al. Neurohumoral features of myocardial stunning due to sudden emotional stress. N Engl J Med. 2005;352:539-48.

6. Cecchi E, Parodi G, Giglioli C, Passantino S, Bandinelli B, Liotta AA, et al. Stress-induced hyperviscocity in the pathophysiology of Takotsubo cardiomyopathy. Am J Cardiol. 2013;111:1523-9.

7. Lazzeroni D, Bini M, Castiglioni P, Moderato L, Ciraci C, Camaiora U, et al. Autonomic function in Takotsubo syndrome long after the acute phase. Int J Cardiol. 2017:231:222-4.

8. Naegele M, Flammer AJ, Enseleit F, Poas S, Frank M, Hirt A, et al. Endothelial function and sympathetic nervous system activity in patients with Takotsubo syndrome. Int J Cardiol. 2016:224:226-30.
Submit your next manuscript to BioMed Central and we will help you at every step:

- We accept pre-submission inquiries

- Our selector tool helps you to find the most relevant journal

- We provide round the clock customer support

- Convenient online submission

- Thorough peer review

- Inclusion in PubMed and all major indexing services

- Maximum visibility for your research

Submit your manuscript at www.biomedcentral.com/submit
Biomed Central 